\title{
The COVID-19 EPIDEMIC IN SERBIA - THE CHALlENGES OF FINDING AN APPROPRIATE BASIS FOR RESPONDING TO A HEALTH CRISIS
}

\section{Accepted 23. 07. 2021 \\ Revised \\ 23. 08.2021 \\ Published \\ 29. 10. 2021}

Keywords

COVID-19

pandemic,

state of

emergency,

emergency

situation,

rule of

law,

response to

emergency
Sofija Nikolić Popadić, Marko Milenković \&

\section{Marta Sjeničić}

Institute of Social Sciences, Belgrade, Serbia.

E-mail: snikolic@idn.org.rs,mmilenkovic@idn.org.rs,msjenicic@idn.org.rs

CORRESPONDING AUTHOR

snikolic@idn.org.rs

Abstract The World Health Organization declared the Covid19 pandemic on 11 March, 2020. Serbia declared a State of Emergency (SoE) on 15 March, just days after the country's first official case, part of an unprecedented global wave of emergency responses, with states reacting differently to the threat of the virus. Decision makers in Serbia opted to declare a SoE, followed by a series of governmental decrees and ministerial orders. This paper examines the Serbian government's initial response. The legislation in force in March 2020 is analysed to explore what possibilities and instruments could have been used, with particular focus on legislation regarding infectious diseases and disaster responses, which allowed for the declaration of an emergency situation, and the introduction of legitimate restrictions to fight the outbreak. The paper concludes that the full potential of all available measures and instruments was not exhausted, especially regarding legislation relating to an emergency situation. 


\section{Introduction - Epidemiological Background}

At the end of 2019, the World Health Organization's China Country Office "was informed of a pneumonia of unknown cause" (later named COVID-19), which was detected in the city of Wuhan in China. ${ }^{1}$ The first case outside of China was reported on January 13, 2020. On January 30, 2020, following the second meeting of the Emergency Committee, which was convened according the International Health Regulations, the World Health Organization Director declared the Covid-19 outbreak a Public Health Emergency of International Concern. ${ }^{2}$ On March 11, 2020, as the Covid-19 continued to spread around the globe, reaching more than one hundred countries, the WHO characterized it as the pandemic outbreak. The number of new cases have rapidly grown, affecting almost all countries in the world. In Europe, the situation in the spring of 2020 in some countries had reached catastrophic proportions. One of the examples of rapid deterioration of the epidemiological situation and severe health crisis could be found in Italy, which was one of the most affected countries in the EU, with daily new cases reaching more than 6500 in March 2020 (De Flora, La Maestra, 2020: 1614).

Serbia was also one of the countries which had significant numbers of new cases, although not at the very beginning of the epidemic. The first case was officially registered in Serbia on March 6, 2020. In the middle of the March 2020 seven - eight new cases per day were officially registered, while that number was higher by the end of the month with between 70 and 100 new cases. The statistics for April showed that the new cases were reaching more than 400 on some days. ${ }^{3}$ Numbers were significantly higher in the second half of the year. By the end of October there were more than 1000 new cases per day. In November they increased to more than 7000 on some days and in December there were a few days with almost 8000 new cases. ${ }^{4}$

\footnotetext{
1 World Health Organization: https://www.who.int/emergencies/diseases/novel-coronavirus-2019/events-asthey-happen.

2 For more details see: World Health Organization: https://www.who.int/emergencies/diseases/novelcoronavirus-2019/events-as-they-happen

3 More data on new cases on a daily basis is available at the official website for the Covid-19 in Serbia: https://covid19.rs/objave-centra-za-javno-zdravlje/

${ }^{4}$ For data about new cases per day, see also the website of the Ministry of Health of the Republic of Serbia: https://www.zdravlje.gov.rs/vest/352037/informacija-o-aktuelnoj-epidemioloskoj-situaciji-u-vezi-sa-novimkorona-virusom-u-republici-srbiji-za-01-decembar-2020-godine-.php
} 
The growing number of new cases and death resulting from from the virus, about which little was known initially, raised a number of questions how to stop the spread and best manage the crisis. The unprecedented challenge presented by COVID-19 to governments triggered a wide range of responses, which have significant implications for human rights and democracy. ${ }^{5}$ Different restrictions limiting human rights, especially the freedom of movement, were applied in some countries in order to try to stop the spread of the virus (Sekalala et al. 2020; United Nations, 2020: 4).

In this paper, we will explore the Serbian government's responses at the beginning of the crisis (March - May 2020), particularly the most important legal aspects of the response: namely, the declaration of the State of Emergency (SoE), which has resulted in derogations from human rights, and the imposition of limitations with the proclaimed aim of curbing the epidemic. The process of the introduction of the $\mathrm{SoE}^{6}$ as a response to the international health crisis, and the means by which Serbia's government achieved this, is examined in the second part, with particular focus on the fifty-three day period between 15 March, 2020, when the SoE was declared amidst the Europe-wide alert over the spread of the corona virus, and 6 May, when the National Assembly of Serbia (Parliament) voted to end it. This section also offers a brief analysis of the decision of the Constitutional Court of Serbia to dismiss all legal claims that the SoE was unconstitutional and proclaimed in an unconstitutional manner, and presents its legal reasoning for so doing (Constitutional Court Decision, 21 May 2020, IUo- $42-2020) .{ }^{7}$ The alternatives to the introduction of the SoE which Serbian law would have allowed at the time are explored in the third section, which is followed by a discussion of modes utilised in the SoE, and those which could have been employed.

\footnotetext{
${ }^{5}$ The comprehensive source and place of debate is available at: https://www.democratic-decay.org/covid-dem ${ }^{6}$ On State of Emergency regimes and relevant standards see inter alia: Lillich (1985: 1072-1081), Özbudun \& Turhan (1995: 1-33), Ferejohn \& Pasquino (2004: 210-239), Keith \& Poe (2004: 1071-1097).

7 Available in Serbian at: http://www.ustavni.sud.rs/page/view/sr-Latn-CS/88-102626/obavestenje
} 


\section{The Declaration of a State of Emergency as an Initial Response to the COVID-19 Crisis in Serbia}

Caught off-balance, like the majority of governments, by the COVID-19 crisis, Serbia initially took a relaxed approach to the encroaching threat (in January and up to late February), eventually coming to terms with the magnitude of the crisis in early March, after the registration of the first official case on 6 March. As cases rose, and with public services seemingly unprepared, the decision was made to declare a SoE. ${ }^{8}$ Widespread derogations from human rights ensued. ${ }^{9}$

\subsection{The Declaration of the State of Emergency}

Article 200 of the Constitution of Serbia ${ }^{10}$ sets out the procedures for States of Emergency, envisaging that the National Assembly may declare one "when the survival of the state or its citizens is threatened by a public danger". Strict limits are set in the Article, which specifies that any SoE declared shall be effective for a maximum of 90 days, upon the expiry of which the National Assembly may extend the SoE for a further 90 days, any such extension requiring an overall majority of the total number of Deputies to vote in favour. The Article also specifies that, during a SoE, the National Assembly shall convene without any special call for assembly and may not be dissolved. Article 200 further states explicitly that when proclaiming a SoE, the National Assembly may prescribe the measures which shall provide for derogations from the human and minority rights guaranteed by the Constitution.

Situations in which it is not possible for the National Assembly to convene are also addressed by the Constitution, which allows the declaration of a SoE to be adopted by the President of the Republic together with the President of the National Assembly and the Prime Minister, under the same terms as by the National Assembly (Constitution of the Republic of Serbia, 2006, Article 200). In such cases the National Assembly must verify it within 48 hours of its proclamation, that is, as soon as it is in a position to convene. If the National Assembly does not verify this decision, it

\footnotetext{
${ }^{8}$ https://www.srbija.gov.rs/vest/en/151398/state-of-emergency-declared-throughout-serbia.php

9 For the comprehensive overview of the declaration of the SoE and human rights derogation see further: Milenković, 2020.

${ }^{10}$ Constitution of the Republic of Serbia, Official Gazette of the Republic of Serbia, no. 98/2006. All of the formulations used in the analysis are from the official translation of the Constitution in English provided on the official web page of the Constitutional Court. Available at: http://www.ustavni.sud.rs/page/view/en-GB/235-100028/constitution
} 
shall cease to be effective upon the end of the first session of the National Assembly held after the declaration of the SoE. The procedure for derogations from human and minority rights in the above circumstances is also delineated. Such derogations may be adopted by the government, in a decree, with the President of the Republic as a co-signatory, and such measures shall be effective for 90 days at the most, and upon expiry of that period may be extended under the same terms as the SoE. As with the declaration of a SoE under such circumstances, the government is obliged to submit the relevant decree to the National Assembly within 48 hours, that is, as soon as the National Assembly is in a position to convene. These measures providing for derogations shall cease to be effective 24 hours prior to the beginning of the first session of the National Assembly held after the declaration of SoE (Constitution of the Republic of Serbia, 2006, Article 200).

Article 202 of the Constitution of Serbia provides for derogations from human and minority rights in a State of Emergency or War, ${ }^{11}$ and envisages that, upon the proclamation of a SoE or War, any such derogations from the rights guaranteed by the Constitution shall be permitted 'only to the extent deemed necessary'. These measures cease to be effective when the SoE or War ends. The Serbian Constitution enumerates seventeen rights which may not be derogated, including the right to a fair trial, the right to dignity and the freedom of religion. Rights which can be limited, however, are the rights to freedom and of movement.

The Constitution requires the National Assembly to declare a SoE, only allowing for the President, Prime Minister and President of the Parliament to make such a declaration in situations in which it is not possible for the National Assembly to convene. Despite many Parliaments across Europe and the world continuing to convene during the peak of the pandemic (Williamson, 2020), and the strong majority enjoyed by the ruling coalition in the Serbian Parliament, which would in any case have backed the decision to declare a SoE, it was the second extraordinary procedure which was chosen on the evening of 15 March (Government Decision of 15 March 2020, no. 25, 2020). Beyond the health risk that convening the National Assembly would pose to MPs, and the Order of the Minister of Health banning gatherings of more than 50 people, the public were offered little or no explanation for the SoE not being declared under the standard, Parliamentary procedure as laid

\footnotetext{
11 The State of War is governed separately by Article 201 of the Constitution.
} 
down in the Constitution. Further confusion was engendered by the fact that only on 19 March did the government (i.e. the Minister for Health) declare an epidemic (Government Order, 19 March 2020, no 37/2020), giving even less justification for the declaration of the SoE without a vote in Parliament. This situation, as will be demonstrated in the following analysis, was briefly considered by the Constitutional Court, which rejected the assertion that it was not possible to claim that Parliament had been prevented from meeting by an epidemic when said epidemic had yet to be declared. One of the great dilemmas in the interpretation of this sequence of events is whether it should be seen as an authoritarian disregard on the part of the governing constellation for Constitutional procedures and institutions, or a (panic) reaction in the face of the looming crisis. ${ }^{12}$ Whichever the case, 42 days of government by decree with the consent of the President followed, during which time there was no parliamentary oversight until Parliament met again on 27 April and confirmed the decision to declare a SoE, and all subsequent decrees and other decisions adopted by the government. This modus operandi has been widely criticised by legal experts, ${ }^{13}$ and several claims (initiatives as defined by the Serbian Constitution) were lodged before the Constitutional Court of Serbia regarding the constitutionality of the declaration and various measures adopted during the SoE. ${ }^{14}$ Even though it remains outside the scope of this analysis, it is important to underline that the introduction of the SoE was coupled with comparatively some of the strictest measures to tackle the spread of virus which included inter alia, total ban of movement for citizens over 65 in towns over 5000 inhabitants (and over 70 in smaller towns and villages), nationwide daily curfews for $12 \mathrm{~h}$ including a total ban to leave dwellings during weekends, and forced hospitalisations even for asymptomatic virus carriers, etc. ${ }^{15}$

\subsection{The Decision of the Constitutional Court on the Declaration of the SoE}

Decision IUo 42-2020 of the Constitutional Court of Serbia was adopted on 21 May, 2020, two full weeks after the Serbian Parliament abolished the SoE. In examining this Decision, we first consider the competence of the Court to scrutinise the constitutionality of general legal acts and then analyse two important questions

\footnotetext{
12 It is considered more comprehensively in: Milenković, 2020.

${ }^{13}$ For critical observations made by Serbian legal experts (in English) see for example: Marinković, 2020.

${ }_{14}$ Among which is the one by the prominent Belgrade Centre for Human Rights, 2020.

15 See further: Milenković, 2020.
} 
which the Court answered (or attempted to answer) in its dismissal of several initiatives. The Constitutional Court is empowered, under Article 167 of the Constitution, to decide on the compliance of laws and other general acts with the Constitution, the generally accepted rules of international law and ratified international treaties. ${ }^{16}$ On 21 May, fifteen days after the SoE ended, the Court decided to dismiss all the initiatives which had been submitted, without explicitly citing any of the potential reasons provided by Law on Constitutional Court, but rather concluding that the "petitioners claims are not constitutionally grounded, i.e. reasons provided do not support the claim that there are grounds to initiate the procedure to examine the compliance of constitutionality and legality of the Decision on the State of Emergency." (Constitutional Court Decision, 21 May 2020, IUo-42-2020, 11). Not going so far as to determine that the initiatives were unfounded, the Court gave a somewhat confusing explanation for the dismissal.

The Court provided a ten-page explanation of its decision to dismiss the initiatives in preliminary procedure, thereby in part turning this decision into an in merit deliberation on the SoE, based around two main issues: whether the state of emergency was constitutional per se, and whether the (above-described) proclamation was in line with the Constitution. The decision to consider and rule on all the initiatives together means that the Court has provided no information as to either the origin or the nature of the initiatives, or indeed their number. A general conclusion would seem to be that applicants have argued that the "conditions were not met for the State of Emergency to be declared" and that the SoE was "declared unconstitutionally by the President, Prime Minister and President of the Parliament instead of by the National Assembly" (Constitutional Court Decision, 21 May 2020, IUo-42-2020, 1). Further arguments are likely to have been that the decision did not specify the length of the state of emergency and that it was not a "proportionate or adequate measure to achieve a declared goal" (Constitutional Court Decision, 21 May 2020, IUo-42-2020, 2). It was underlined in the decision that a common theme in all the initiatives was that there were no reasons preventing Parliament from convening and adopting the decision, and furthermore that no decision of the Executive, in this case the Order on banning gatherings in closed spaces (Government Decision, -- March 2020, no. 25/2020) issued by the Minister of Health, could be a reason for the body not to convene. The decision includes the

${ }^{16}$ For a detailed explanation of procedure see: Milenković, 2020. 
assertion by petitioners that "this kind of action would lead to an institutionalised power takeover by the executive and concentration of power, contrary to constitutional separation of powers between Parliament, the executive and the judiciary" (Constitutional Court Decision, 21 May 2020, IUo-42-2020, 2). By stressing that the epidemic could not be used as an argument for not convening Parliament as it was not proclaimed until 19 March (Government Decision, 19 March 2020, no 31/2020), the petitioners also invoked the general ban on retroactivity (Article 197 of the constitution) (Constitutional Court Decision, 21 May 2020, IUo-42-2020, 2).

The Court's analysis of what constitutes an emergency is somewhat negligible, with only one paragraph devoted to a discussion of the European Court of Human Rights (ECtHR) case law, and only one reference made to any scholarly work on the subject. The Court pointed out that the decision to declare the SoE was of a specific nature, as it represented an act by which the State was taken from the regular to an emergency constitutional State, whose legal basis was the "necessity, understood as the supreme need to preserve the constitution, and in that matter, the source allowing acceptance of legislation derogating from the formal text of the constitution, but which ought to preserve the essence of the constitution" (Constitutional Court Decision, 21 May 2020, IUo-42-2020, 8).

The Court offered very few arguments regarding the second main question whether the proclamation itself was made in a constitutional manner. The most striking of these is, perhaps, that "The Constitution does not determine who assesses and on the basis of which criteria and reasons that the National Assembly is not able to meet." (Constitutional Court Decision, 21 May 2020, IUo-42-2020, 9). In its subsequent analysis of the relevant legislation governing the work of the National Assembly, the Court concluded that "none of the above acts stipulates the obligation of the Speaker of the National Assembly to convene this body to declare a State of Emergency before independently assessing whether the National Assembly is able to meet." (Constitutional Court Decision, 21 May 2020, Decision IUo-42-2020, 9). The Decision by the Constitutional Court of Serbia should come as no surprise. Based on her study of a number of the Court decisions post 2000, Beširević has highlighted the "play-it-safe strategy the Court applied in the most controversial political cases, in which it would have been possible to initiate changes in public policy, including cases concerning constitution-making, the state of emergency, 
judicial reform, and political decentralisation.” (Beširević, 2014: 954 - 979; see also Papić \& Djerić, 2018: 954). With this in mind, we proceed with our analysis of what could have been used as plausible alternatives to the declaration of SoE.

\section{The Declaration of an Emergency Situation as a Possible Response to the Health Crisis?}

As discussed in the previous section, Serbian decision makers have opted for a declaration of SoE in order to combat the health crisis. One of the questions we deal with in this paper is whether a different approach could have been applied in resolving this crisis. In order to answer this question, we start by analysing the legislation that was in force in March 2020. Two laws that are particularly important in this regard are the Law on Disaster Risk Reduction and Emergency Situations Management and the Law on Protection of the Population from Infectious Diseases. Could they have been the starting point for the possible decision-making at the time of the pandemic outbreak, and could their application lead to a different response to the health crisis by declaring the emergency situation?

\subsection{Legislation providing a basis for an emergency situation}

A declaration of emergency situation in Serbia is regulated by the Law on Disaster Risk Reduction and Emergency Situations Management from 2018. According to the Law "An emergency situation is declared when the risks and threats or consequences of a catastrophe on the population, ... are of such scope and intensity that their occurrence or consequences cannot be prevented or eliminated by regular action of competent bodies and services, therefore, for their mitigation and elimination, it is necessary to use special measures, additional forces and resources with an intensified mode of operation." (Law on Disaster Risk Reduction and Emergency Situations Management, 2018, Article 38 (1)). The catastrophe which can form the basis for a declaration of emergency situation is as a natural disaster, which encompass a wide range of phenomena including pandemics and epidemics of infectious diseases (Law on Disaster Risk Reduction and Emergency Situations Management, 2018, Article 2). According to that, the COVID-19 epidemic in Serbia could have been the reason for declaring the emergency situation. As the epidemic was a risk and threat for the 
whole country, we will analyse the procedure for declaring the emergency situation for the whole territory of the Republic of Serbia. ${ }^{17}$

The Law prescribes that an emergency situation is to be declared immediately upon learning of the imminent danger of its occurrence, or "after its occurrence, if the immediate danger of an emergency situation could not have been foreseen or if due to other circumstances it could not have been declared immediately after learning about the immediate danger of its occurrence" (Law on Disaster Risk Reduction and Emergency Situations Management, 2018, Article 38 (2), (3)). For the territory of the Republic of Serbia the emergency situation is declared and abolished by the government, at the proposal of the Republic Headquarters for Emergency Situations (Law on Disaster Risk Reduction and Emergency Situations Management, 2018, Article 39). Generally, emergency headquarters at different levels are established to monitor disaster risk reduction activities and to coordinate and manage emergencies. Among their many competencies is assessing the threat of an emergency situation and submitting proposals for declaring and abolishing the emergency situation (Law on Disaster Risk Reduction and Emergency Situations Management, 2018, Article 41, 43). If the Republic Headquarters for Emergency Situations does not act according to the law, and if there are conditions for declaring the emergency situation, the government is entitled to declare it, at the proposal of the Ministry of Interior (Law on Disaster Risk Reduction and Emergency Situations Management, 2018, Article 39, 40).

As explained in the first paragraph of this section, epidemics of infectious diseases constitute one of the reasons to declare an emergency situation. Accordingly, the Republic Headquarters for Emergency Situations (or in case of absence of its action, the Ministry of Interior) could have proposed to the government to declare the emergency situation. According to the Law, an emergency situation should be declared immediately upon learning of the imminent danger of its occurrence. After the Order on the Declaration of Epidemic of Communicable Disease COVID-19, from 19 March, it was clear that the epidemic posed a threat to the whole country, which would require a declaration of emergency situation. However, as previously explained, the decision instead was made to declare a SoE four days before the

\footnotetext{
17 According to article 39 of the Law on Disaster Risk Reduction and Emergency Situations Management "A state of emergency for the territory of the Republic of Serbia is declared when there is an immediate danger that will affect, or has already affected at least two local self-government units, and the assessment is that the danger or its consequences will spread and that all capacities of the Republic of Serbia must be engaged in prevention, elimination, ie mitigation of consequences."
} 
epidemic was officially declared. Compared to a state of emergency, which can last for a limited period of time, the maximum duration of an emergency situation is not prescribed. The Law on Disaster Risk Reduction and Emergency Situations Management states that "the emergency situation is lifted by the cessation of danger, ie the cessation of the need to implement measures for protection and rescue from disasters" (Article 38 (4)).

One of the questions that arises is whether declaring a state of emergency would enable adequate action to prevent the spread of a contagious disease or whether it was necessary to declare a state of emergency which enabled stricter limitations upon human rights. In order to find an answer, we analyse the Law on Protection of the Population from Infectious Diseases, which prescribes the measures which can be applied in the case of emergencies, such as outbreaks of infectious diseases, new or insufficiently known infectious diseases, "that may endanger human health and lives and in which there is an imminent danger of mass transmission of infectious diseases" (Law on Protection of the Population from Infectious Diseases, 2016, Article 51)

\subsection{Legislation governing infectious diseases and disaster responses}

The Law on Protection of the Population from Infectious Diseases defines the emergency situation as one win which the risks and threats or consequences of catastrophe, emergency events and other dangers for population, environment or goods are so voluminous and intensive that their occurrence or consequences cannot be prevented or obviated through regular activities, but they require specific measures«.

Provisions of this Law have been amended during the first year of the COVID-19 pandemic, by widening and strengthening measures that could be implemented in the emergency situation. However, even before the COVID-19 pandemic, Article 51 of the Law (as abovementioned: Official Gazette, No. 15/2016) stipulated that in case of emergencies (natural disasters and catastrophes, outbreaks of infectious diseases, new or insufficiently known infectious diseases and suspected use of biological agents, etc.) that may endanger human health and lives and in which there is an imminent danger of mass transmission of infectious diseases, the following measures are implemented: 1) organizing, planning and ensuring the implementation of measures for the prevention and control of infectious diseases; 2) rapid epidemiological assessment in order to urgently take immediate measures to protect 
the population; 3) epidemiological surveillance in an emergency situation, by introducing an early warning system while there are reasons; 4) transport, isolation and quarantine if there is an indication; 5) activation of the emergency communication system; 6) obligatory participation of health institutions, private practice, entrepreneurs and citizens in suppressing risks to public health and use of certain facilities, equipment and means of transport in order to prevent and suppress the transmission of infectious diseases, based on the order of the Minister. For the implementation of emergency measures, this Law refers to the Law on Disaster Risk Reduction and Emergency Situations Management.

Article 52 of the Law on Protection of the Population from Infectious Diseases stipulated that based on the proposal of the Republic Expert Commission for Protection of the Population from Infectious Diseases (hereinafter: Commission) and the Institute for Public Health of Republic of Serbia (hereinafter: Institute), the Minister may order: a) the prohibition of gatherings in public places; b) restrictions of population movements in the areas affected by the emergency situation; c) travel bans or restrictions; g) the prohibition or restriction of trade in certain types of goods and products; e) emergency vaccination. These measures shall last until the cessation of the danger.

Article 53 stipulated that, in order to prevent the introduction of infectious diseases into the country, to suppress and prevent their transmission to other countries, the Minister, on the proposal of the Commission and the Institute, may order measures to protect the population from infectious diseases, as follows: 1) a ban on travel to a country where there is an epidemic of an infectious disease; 2) prohibition of movement of the population, ie restriction of movement of the population in the areas affected by a certain contagious disease, ie epidemic of that contagious disease; 3) the prohibition or restriction of trade in certain types of goods and products; 4) obligatory participation of health institutions, other forms of performing health activities, other legal entities, entrepreneurs and citizens in the suppression of infectious diseases and the use of certain facilities, equipment and means of transport for the purpose of combating infectious diseases. The measures prescribed by the Article 53 may last as long as there is a danger of introducing a contagious disease into the country, i.e., of spreading an epidemic of a contagious disease. 
It is clear that most of the measures that were undertaken under the SoE would have also been possible had the Emergency Situation been proclaimed. The scope of the measures is, under the current version of the Law, broader. (in line with the experiences drawn from the COVID-19 pandemic). Nevertheless, the previous version of the Law (in force during the period of SoE) could have allowed for a considerable range of possibilities (restrictions), as well. For example, measures such as a ban on travelling or prohibitions/restrictions of movement would have given similar effect under the emergency situation, as under the SoE. However, it is dubious whether the strictest restrictions that were posed under SoE, would have been possible under the emergency situation. This remains an open issue, since the provisions of the Law on Protection of the Population from Infectious Diseases are quite general, and could be interpreted differently, if this Law had been applied. Namely, "prohibition" and "restriction" could mean total ban, but also a partial limitation of travelling or movement. Therefore, we can draw the conclusion that, due to the widely formulated provisions of the Law, it was open to wide interpretation, subject to the Constitution Court scrutiny.

In addition, by enacting the new Law on Protection of the Population from Infectious Diseases in 2016, national provisions were harmonised with the World Health Organisation (hereinafter: WHO) International Health Regulations (hereinafter: IHR). Law stipulated in the Article 12 that the Institute of Public Health of Serbia performs the activities of the National Center for the Implementation of the IHR. In the event of emergency (public health risk), the Institute exchanges information with the WHO, checks and reports the case to WHO and adopts an Action Plan for the implementation of the IHR. In case of an emergency, the Minister of Health forms a joint body, for the purpose of preventing and suppressing the emergency. In accordance with the IHR, the Institute submits a notification on the occurrence of an infectious disease, epidemic or other public health emergency of international concern to the WHO Regional Office for Europe and other international organizations or countries, in accordance with accepted international obligations. These provisions have already provided a line of steps for cases involving public health emergencies of international concern. 
IHR purpose is to prevent, protect, control and provide the public health response to the international spread of disease, in the way which is proportional and limited to public health emergencies, and at the same time, to avoid the unnecessary disturbance of international traffic and trade. IHR regulates: (a) a scope not limited to any specific disease or manner of transmission, but covering "illness or medical condition, irrespective of origin or source, that presents or could present significant harm to humans"; (b) State Party obligations to develop certain minimum core public health capacities; (c) obligations on States Parties to notify WHO of events that may constitute a public health emergency of international concern according to defined criteria; (d) provisions authorizing WHO to take into consideration unofficial reports of public health events and to obtain verification from States Parties concerning such events; (e) procedures for the determination by the Director-General of a "public health emergency of international concern" and issuance of corresponding temporary recommendations, after taking into account the views of an Emergency Committee; (f) protection of the human rights of persons and travellers; and $(\mathrm{g})$ the establishment of National IHR Focal Points and WHO IHR Contact Points for urgent communications between States Parties and WHO (Sjeničić \& Miljuš, 2014: 235).

Therefore, all Member States of the WHO, that were signatories of the IHR, were obliged to harmonise their national legislation, and especially their field capacities, with IHR provisions. If these capacities had been in place, and IHR provisions had been incorporated and implemented, in Serbia, but also world-wide, the COVID-19 virus may very well have been much better contained.

\section{Discussion - Could Serbia have achieved the Same Goal with an Emergency Situation?}

As shown in the previous sections, the Law on Disaster Risk Reduction and Emergency Situations Management and the Law on Protection of the Population from Infectious Diseases could provide a basis for issuance of a declaration of the emergency situation as a possible response to the health crisis. These laws could allow a number of measures to be introduced in order to combat the crisis without declaring the state of emergency. The question remains whether those measures could have been enough to adequately deal with the many challenges created by the Covid-19 epidemics in Serbia. 
Some claims that the declaration of an emergency situation, as mentioned above, would have been sufficient to address the public health crisis, were also considered by the Constitutional Court. The Court emphasised that an emergency situation is a legal instrument based on ordinary legislation (Law on Public Health, 2016; Law on Protection of the Population from Infectious Diseases, 2016; Law on Disaster Risk Reduction and Emergency Situations Management, 2018) and not the Constitution, adding that "In constitutional law doctrine, the prevailing view is that it is difficult, if not impossible, to make a clear distinction between a State of Emergency and an emergency situation" (Constitutional Court Decision, 21 May 2020, Decision IUo-42-2020, 6). The court pointed out that: "...measures of deviation from human rights, provided that they are justified and proportionate, as well as other measures that can be adopted in a State of Emergency ... give far greater opportunities for the state to react in a timely and effective manner in eliminating public danger to the lives of citizens". In the words of the Court: "the legal 'capacity' of the extraordinary situation does not even guarantee such an effective response of state bodies and services (insufficient efficiency of services, problems in coordination, impossibility of fundamental health reorganisation, etc.)" (Constitutional Court Decision, 21 May 2020, IUo-42-2020, 6-7). The Court continued: "when declaring a State of Emergency, other factors that justify such a decision must be taken into account, and in this particular case it would be the state and capacities of the health system, the health culture of citizens, mentality, age structure of the nation, etc." (Constitutional Court Decision, 21 May 2020, Decision IUo-42-2020, 7).

Jointly considered, the provisions of the Law on Disaster Risk Reduction and Emergency Situations Management and the Law on Protection of the Population from Infectious Diseases seem to provide enough legal tools and base to substantially implement similar measures to those undertaken under the SoE, but in a substantially more acceptable manner, and which would be in conformity both with the law and Constitution. Namely, the SoE was declared (before the declaration of epidemic) in a situation where other legal tools were available, , well-established, normatively possible and in line with the tripartite constitutional separation of powers between Parliament, the executive and the judiciary. Accordingly, substantially the same results achieved by the SoE could have been also achieved through a proclamation of emergency situation. Therefore, the proclamation of SoE was rushed and undermines the notion of separation of powers, which is critically important in a democracy. Issuance of the SoE was more in line with authoritarian ways of governing and 
accordingly should be avoided in the future. It is important to note, that the public health crisis and the government measures were ongoing events when this analysis began, and at the time of its conclusion, the situation is still unfolding with new measures expected to come in force across jurisdictions. Furthermore, it also is important to note that many other governments decided to resort to some of the strictest measures and human rights limitations, including curfews, only in the later stages of the COVID-19 crisis towards the end of 2020. The conclusions arrived at here should be revisited in the future, when the full picture of events may be clearer. Additionally, comprehensive comparative studies should also be employed to correctly position this study in a broader context.

\section{$5 \quad$ Conclusions}

The aim of this paper has been to present a critical assessment of the major legal aspects of the Serbian government's actions in the face of the health crisis, namely the introduction of the SoE in order to respond to the COVID-19 outbreak. We analysed the declaration of the $\mathrm{SoE}$ and the emergency situation as a possible reaction to combat the health crisis. One of the conclusions from this comparison is that the advantage of the declaration of emergency situation for handling the health crisis is that there is no prescribed duration, as compared to the SoE which can last up to 90 days and could be prolonged only once for the same duration. Therefore, emergency situation gives the opportunity to apply necessary measures as long as there is a danger and a need for their implementation (ie. it is lifted by the cessation of danger, the cessation of the need to implement measures for protection and rescue). The advantage of the declaration of the $\mathrm{SoE}$ is that it allows the introduction of stricter measures and greater restrictions, if found necessary by authorities. Having in mind the threat from the unknown virus, the decision to declare the SoE might be attributed to the desire on the part of decision makers to apply the strictest measures to combat the health crisis. While it is clear, from this research, that other options, apart from the introduction of the SoE and use of curfews and other strict measures, were available under existing systems for responding to epidemic situations and other emergencies, along with a comprehensive set of measures specifically designed to flatten an epidemic curve, those other options were far more difficult to enforce and police. Therefore, in the context of the above- described unpreparedness, the government resorted to a 
simple, yet admittedly onerous solution in order to try to curb the first wave of the pandemic in the country.

\section{Acknowledgments}

This paper was written as part of the 2021 Research Program of the Institute of Social Sciences with the support of the Ministry of Education, Science and Technological Development of the Republic of Serbia.

\section{Legislation, Acts, Regulations and Court Decisions}

Constitutional Court Decision, 21 May 2020, Decision IUo-42-2020.

Constitution of the Republic of Serbia, Official Gazette of the Republic of Serbia, no. 98/2006.

Decision on the Proclamation of the State of Emergency, in Official Gazette of the Republic of Serbia, no. $25 / 2020$.

Order on the Declaration of Epidemic of Communicable Disease COVID-19, Official Gazette of the Republic of Serbia, no. 37/2020.

The Law on Disaster Risk Reduction and Emergency Situations Management, Official Gazette of the Republic of Serbia, no. 87/2018.

The Law on Protection of the Population from Infectious Diseases, Official Gazette of the Republic of Serbia, no.15/2016, 68/2020 and 136/2020.

\section{References}

Beširević, V. (2014) Governing Without Judges: the Politics of the Constitutional Court in Serbia, International Journal of Constitutional Law, 12(4), pp. 954-979.

Belgrade Centre for Human Rights (2020), BCHR Initiates Review of Constitutionality of the Decree on State Emergency Measures and the Order Restricting and Probibiting Movement of Individuals in the Territory of the Republic of Serbia, March 31, 2000, retrieved from:

http://www.bgcentar.org.rs/bgcentar/eng-lat/bchr-initiates-review-of-constitutionality-ofthe-decree-on-state-emergency-measures-and-the-order-restricting-and-prohibiting-

movement-of-individuals-in-the-territory-of-the-republic-of-serbia/ (September 2, 2021).

Data on new cases of Covid-19 in Serbia on a daily basis, retrieved from: https://covid19.rs/objavecentra-za-javno-zdravlje/ (September 2, 2021)

De Flora, S. \& La Maestra, S. (2020) Growth and decline of the COVID-19 epidemic wave in Italy from March to June 2020, Journal of Medical Virology, pp. 1613-1619, doi: 10.1002/jmv.26499

Ferejohn, J. \& Pasquino, P. (2004) The Law of the Exception: a Typology of Emergency Powers, International Journal of Constitutional Law, 2(2), pp. 210-239.

Keith, L.C. \& Poe. S.C. (2004) Are Constitutional State of Emergency Clauses Effective? An Empirical Exploration, Human Rights Quarterly, 26(4), pp. 1071-1097.

Lillich, R. (1985) The Paris Minimum Standards of Human Rights Norms in a State of Emergency. American Journal of International Law, 79(4), pp. 1072-1081.

Marinković, T. (2020) The Fight against Covid-19 in Serbia: Saving the Nation or Securing the Re-election?, in VerfassingsBlog, 2020, retrieved from: https://verfassungsblog.de/fight-against-covid-19-inserbia-saving-the-nation-or-securing-the-re-election/ (1 September 2021).

Milenković, M. (2020) Responses to the Covid-19 Crisis in Serbia- Democracy and Rule of law on Ventilators?, Percorsi costiturionali 2, pp. 441-468.

Ministry of Health of the Republic of Serbia, data on new cases of Covid-19 in Serbia, retrieved from: https://www.zdravlje.gov.rs/vest/352037/informacija-o-aktuelnoj-epidemioloskoj-situaciji- 
u-vezi-sa-novim-korona-virusom-u-republici-srbiji-za-01-decembar-2020-godine-.php (September 2, 2021).

Özbudun, E. \& Turhan, M. (1995) Emergency Powers, Venice Commission, Report CDL-STD (1995) 012, pp. 1-33.

Papić, T. \& Djerić, V. (2018) On the Margins of Consolidation: the Constitutional Court of Serbia, Hague Journal on the Rule of Law, 10.

Sekalala, S., Forman, L., Habibi, R. \& Meier, B.M. (2020) Health and human rights are inextricably linked in the COVID-19 response, BMJ Global Health, (5), pp. 1-7, doi:10.1136/bmjgh-2020003359 .

Sjeničić, M. \& Miljuš, D. (2014) Public Health Threat as the Emergency Situation, Archibald Reiss Days, Thematic conference proceedings of international significance (323-332), Vol. II.

United Nations (2020) COVID-19 and Human Rights We are all in this together, April 2020, retrieved from: https://www.un.org/victimsofterrorism/sites/www.un.org.victimsofterrorism/files/un__human_rights_and_covid_april_2020.pdf (Septemebr 2, 2021).

Williamson, A. (2020) How are Parliaments Responding to the Coronavirus Pandemic?, Hansard Society, 2020, April 8, 2021, retrieved from: https://www.hansardsociety.org.uk/blog/how-areparliaments-responding-to-the-coronavirus-pandemic (September 2, 2021).

World Health Organization, Rolling updates on coronavirus disease (COVID-19), July 31, 2000, retrieved from: https://www.who.int/emergencies/diseases/novel-coronavirus-2019/events-as-theyhappen (September 2, 2021). 